\title{
ŽÁROVZDORNÉ VLASTNOSTI A KOROZNÍ ODOLNOST FORSTERIT-SPINELOVÉ KERAMIKY S VYUŽITÍM VYSOKOTEPLOTNÍHO POPÍLKU
}

\author{
REFRACTORY PROPERTIES AND CORROSION RESISTANCE \\ OF FORSTERITE-SPINEL CERAMICS WITH UTILIZATION OF FLY ASH
}

\author{
Ing. Martin Nguyen ${ }^{1 *}$; doc. Ing. Radomír Sokolár̆, Ph.D. ${ }^{1}$ \\ ${ }^{1}$ Vysoké učení technické v Brně, Fakulta stavební, Veveři 331/95, 60200 Brno, Česká republika \\ *korespondenční autor: nguyen.m@fce.vutbr.cz
}

\section{PŮVODNÍ VĚDECKÝ PŘíSPĚVEK}

ORIGINAL SCIENTIFIC ARTICLE

\begin{abstract}
ABSTRAKT CZ
Tento článek se zabývá procesem syntézy žárovzdorné forsterit-spinelové keramiky za použití vysokoteplotního popílku a reaktivního oxidu hlinitého jako zdroje oxidu hlinitého. Vstupní suroviny byly rozemlety, smíchány v různém poměru a vypáleny při $1500{ }^{\circ} \mathrm{C}$ po dobu $2 \mathrm{~h}$. Vypálené zkušební vzorky byly charakterizovány pomocí RTG difrakční analýzy a rastrovacího elektronového mikroskopu. Rovněž byla zkoumána pórovitost, nasákavost, objemová hmotnost, žárovzdornost, únosnost $\mathrm{v}$ žáru, odolnost proti změnám teplot a korozní odolnost vůči účinkům taveniny železa. Výsledné vlastnosti byly poté porovnány v závislosti na zdroji oxidu hlinitého. Př́ítomnost spinelu ve vzorcích vedla ke zlepšení mikrostruktury, mechanických vlastností, odolnosti proti změnám teplot a také korozní odolnosti. Zejména směsi s 10-20 \% spinelu měly nejslibnější výsledky.
\end{abstract}

Klíčová slova: Forsterit; spinel; popílek; žárovzdornost; korozní odolnost

\section{ABSTRACT}

This article examines the process for the synthesis of forsterite-spinel refractory ceramics with utilization of fly ash and reactive alumina as sources of aluminium oxide. Raw materials were milled, mixed in different ratios and sintered at $1500{ }^{\circ} \mathrm{C}$ for $2 \mathrm{~h}$. Sintered samples were characterized by XRD and SEM. Porosity, water absorption, bulk density, refractoriness, refractoriness under load, thermal shock resistance and corrosion resistance to the effects of molten iron were also investigated. The resulting properties were then compared depending on the source of aluminium oxide. Presence of spinel in fired samples led to improved microstructural and mechanical properties, thermal shock resistance and corrosion resistance. In particular, mixtures with 10-20\% of spinel had the most promising results.

Key words: Forsterite; spinel; fly ash; refractoriness; corrosion resistance 


\section{1 ÚVOD}

Žárovzdorná forsteritová keramika je důležitým typem materiálu, chemický vzorec forsteritu je $2 \mathrm{MgO} \cdot \mathrm{SiO}_{2}$ a forsterit se využivá především $\mathrm{v}$ metalurgickém a cementářském průmyslu jako vyzdívka metalurgických a rotačních pecí díky vysoké teplotě tání forsteritu až $1890{ }^{\circ} \mathrm{C}[1,2,3]$. Forsterit je také využíván $\mathrm{v}$ elektrotechnickém průmyslu pro spojení keramiky s kovem, a to díky poměrně vysokému koeficientu délkové teplotní roztažnosti, který je podobný koeficientu kovi̊ $[4,5]$.

Kvůli vysokému koeficientu délkové teplotní roztažnosti má čistý forsterit poměrně malou odolnost proti náhlým změnám teplot. Tuto vlastnost lze vylepšit přidáním hořečnato-hlinitého spinelu (MAspinel; spinel). Přidáním již malého množství (10-20 \%) spinelu dochází ke zlepšení mikrostruktury, mechanických vlastností a zejména zvýšení odolnosti proti změnám teplot $[6,7]$. Spinel lze syntetizovat $\mathrm{z}$ oxidu hlinitého a oxidu hořečnatého, jeho chemický vzorec je $\mathrm{MgO} \cdot \mathrm{Al}_{2} \mathrm{O}_{3}$.

Hlavním cílem tohoto příspěvku bylo stanovení vlivu různých surovinových směsí na výsledné vlastnosti forsterit-spinelové keramiky. Byly zkoumány zejména fyzikálně-mechanické vlastnosti jako jsou pórovitost, nasákavost, objemová hmotnost nebo pevnost v tahu za ohybu, fázové složení pomocí RTG difrakční analýzy, mikrostruktura pomocí rastrovacího elektronového mikroskopu, žárovzdorné vlastnosti a korozní odolnost vi̊či účinkům taveniny železa.

Vysokoteplotní popílek, jenž je produkován jako druhotná surovina z elektráren spalující uhlí, lze využít jako levný zdroj oxidů hlinitého a křemičitého. Využitím i minoritního množství druhotné suroviny jako vstupní je velmi př́nosné pro ekologii a má také pozitivní enviromentální vliv na udržitelný rozvoj v budoucnosti. Oxid křemičitý a hlinitý lze využít právě při slinování žárovzdorné keramiky. Elektrárenský popílek byl využitý v mnoha vědeckých studiích s dobrými výslednými vlastnostmi $[8,9]$. Spinelová keramika se společně s magnezitem především využívá také jako vyzdívka rotačních pecí pro výrobu cementu a vápna díky velmi vysokému bodu tání $2135^{\circ} \mathrm{C}$, nízké teplotní roztažnosti v porovnání $\mathrm{s}$ forsteritovou keramikou a také dobrou odolností proti náhlým změnám teplot a korozní odolností $[6,7,10]$. Navzdory využití popílku pro syntézu žárovzdorné hlinito-křemičitanové keramiky bylo provedeno jen nemnoho výzkumů zabývajících se využití elektrárenského popílku pro syntézu jiných žárovzdorných materiálů obsahujících oxidy křemíku anebo hliníku, jako je například forsteritspinelová keramika. Předchozí výzkum také prokazuje úspěšné využití popílku jako zdroje oxidu hlinitého pro syntézu forsterit-spinelové keramiky. [11, 12]

\section{METODIKA}

Vstupní suroviny byly získány z několika různých lokalit. Kalcinovaný kaustický magnezit (CCM 85) ze Slovenských magnezitových závodů v Jelšavě, olivín od norské společnosti A/S Olivin, reaktivní oxid hlinitý CTC 22 od společnosti Almatis, Německo, vysokoteplotní popílek z elektrárny Mělník a kaolin Sedlec Ia od společnosti Sedlecký kaolin. Chemické složení vstupních surovin je zobrazeno v Tab. 1 a bylo stanoveno pomocí chemické analýzy a rentgenové fluorescence (XRF).

Celkem bylo navrženo 6 různých surovinových směsí, které byly rozděleny do dvou sad v závislosti na zdroji oxidu hlinitého pro syntézu spinelu. První sada tří různých směsí obsahovala jako zdroj oxidu hlinitého reaktivní oxid hlinitý CTC 22 (označeny ROH10-ROH30). Druhá sada tří různých směsí obsahovala jako zdroj oxidu hlinitého vysokoteplotní popílek (označeny VP10-VP30). Č́slovka v názvu směsí označuje podíl popílku v množství $10 \%, 20 \%$ a $30 \%$. Z chemického složení bylo vypočítáno přesné množství oxidu hlinitého ve směsích s popílkem a v závislosti na něm bylo do směsí ROH prridáno poměrné množství reaktivního oxidu hlinitého, aby bylo dosaženo stejného molárního 
poměru a označení směsí s reaktivním oxidem hlinitým tedy koresponduje obsahem oxidu hlinitého se směsmi s popílkem. Surovinové složení všech navržených směsí je zobrazeno v Tab. 2.

\begin{tabular}{|c|c|c|c|c|c|c|c|}
\hline Vstupní suroviny & $\begin{array}{c}\mathbf{M g O} \\
{[\%]}\end{array}$ & $\begin{array}{c}\mathbf{S i O}_{2} \\
{[\%]}\end{array}$ & $\begin{array}{c}\mathbf{A l}_{2} \mathbf{O}_{3} \\
{[\%]}\end{array}$ & $\begin{array}{c}\mathbf{C a O} \\
{[\%]}\end{array}$ & $\begin{array}{c}\mathbf{F e}_{2} \mathbf{O}_{3} \\
{[\%]}\end{array}$ & $\begin{array}{c}\mathbf{K}_{2} \mathbf{O}_{+} \mathbf{N a}_{2} \mathbf{O} \\
{[\%]}\end{array}$ & $\begin{array}{c}\mathbf{Z} \check{Z}^{*} \\
{[\%]}\end{array}$ \\
\hline CCM 85 & 85,0 & 0,5 & 0,8 & 5,2 & 7,30 & 0,20 & 1,0 \\
\hline Olivín & 24,1 & 64,7 & 1,0 & 0,7 & 8,80 & 0,50 & 1,0 \\
\hline Reaktivní oxid hlinitý & 0,0 & 0,0 & 99,7 & 0,0 & 0,03 & 0,12 & 0,1 \\
\hline Popílek & 1,4 & 57,3 & 29,3 & 2,2 & 5,10 & 1,70 & 1,2 \\
\hline Kaolín Sedlec Ia & 0,5 & 46,8 & 36,6 & 0,7 & 0,85 & 1,20 & 13,2 \\
\hline
\end{tabular}

* ztráta žíháním

Tab. 1 Chemické složení vstupních surovin

\begin{tabular}{|c|c|c|c|c|c|}
\hline $\begin{array}{c}\text { Označení } \\
\text { směsi }\end{array}$ & $\begin{array}{c}\text { CCM 85 } \\
{[\mathbf{h m . ~ \% ] ~}}\end{array}$ & $\begin{array}{c}\text { Olivín } \\
{[\mathbf{h m} \text { \%] }}\end{array}$ & $\begin{array}{c}\text { Reaktivní oxid } \\
\text { hlinitý [hm. \%] }\end{array}$ & $\begin{array}{c}\text { Vysokoteplotní } \\
\text { popílek [hm. \%] }\end{array}$ & $\begin{array}{c}\text { Kaolín Sedlec Ia } \\
\text { [hm. \%] }\end{array}$ \\
\hline VP10 & 43,2 & 41,8 & - & 10,0 & 5,0 \\
\hline ROH10 & 41,0 & 51,1 & 2,9 & - & 5,0 \\
\hline VP20 & 44,1 & 30,9 & - & 20,0 & 5,0 \\
\hline ROH20 & 39,8 & 49,4 & 5,8 & - & 5,0 \\
\hline VP30 & 45,0 & 20,0 & - & 30,0 & 5,0 \\
\hline ROH30 & 38,6 & 47,8 & 8,6 & - & 5,0 \\
\hline
\end{tabular}

Tab. 2 Surovinové složení navržených směsí

Všechny směsi byly připraveny rozemletím hrubších vstupních surovin tak, aby propadly sítem o velikosti oka $0,064 \mathrm{~mm}$. Po smíchání vstupních surovin byly směsi homogenizovány v rotačním mechanickém homogenizátoru po dobu 24 hodin. Po smíchání s vodou bylo pomocí Pfefferkornova přístroje zhotoveno plastické těsto s optimální plasticitou. $Z$ něj byly poté formovány zkušební vzorky ve tvaru hranolu o rozměrech $20 \times 25 \times 100 \mathrm{~mm}$ a ve tvaru kužele o výšce $50 \mathrm{~mm}$ a průměru $50 \mathrm{~mm}$. Ze stejného plastického těsta také zkušební žároměrky ve tvaru jehlanu dle ČSN EN 993-13. Pro zkoušku korozní odolnosti byly vytvořeny zkušební kelímky ze všech směsí o rozměrech $100 \times 100 \times$ $76 \mathrm{~mm}$ s dutinou ve středu ve tvaru válce s průměrem $55 \mathrm{~mm}$ a hloubkou $55 \mathrm{~mm}$. Zkušební vzorky byly poté vysušeny v laboratorní sušárně při teplotě $105^{\circ} \mathrm{C}$ do konstantní hmotnosti. Po sušení následoval výpal zkušebních vzorků při teplotě $1500{ }^{\circ} \mathrm{C} \mathrm{s}$ teplotním nárůstem $4{ }^{\circ} \mathrm{C} / \mathrm{min}$ a dobou výdrže 2 hodiny při maximální teplotě.

Vypálené zkušební vzorky byly poté podrobeny několika experimentům. Zdánlivá pórovitost, nasákavost a objemová hmotnost byly stanoveny dle ČSN EN 993-1. Délkové změny výpalem dle ČSN EN 993-10. Žárovzdornost byla provedena dle ČSN EN 993-12 na zkušebních žároměrkách, které byly umístěny do pozorovací pece $\mathrm{s}$ fotoaparátem, jenž umožňuje pozorování v reálném čase. Únosnost v žáru dle ISO 1893 byla provedena na válcových vzorcích a byla sledována teplota při $0,5 \%$ deformaci (T0,5). Odolnost proti změnám teplot dle ČSN EN 993-11 metoda B, jejíž výsledkem je parametr reziduální pevnost $\mathrm{v}$ ohybu, který je definován jako poměr pevnosti v tahu za ohybu cyklovaných vzorků k pevnosti v tahu za ohybu necyklovaných vzorků. Korozní odolnost byla testována pomocí kelímkové zkoušky podle ČSN P cEN 15418 a korozní látkou bylo železo, které bylo vloženo do kelímků a poté 
vypáleno při teplotě tavení železa $1535^{\circ} \mathrm{C}$ s teplotním nárůstem $4^{\circ} \mathrm{C} / \mathrm{min}$ po dobu 5 hodin. RTG difrakční analýza pro stanovení mineralogického složení se zdrojem záření $\mathrm{CuK} \alpha$, urychlovací napětí $45 \mathrm{kV}$ a proud $40 \mathrm{~mA}$. Mikrostruktura a vyhodnocení korozní odolnosti bylo pozorováno pomocí rastrovacího elektronového mikroskopu s prvkovou sondou.

\section{VÝSLEDKY A DISKUZE}

Výsledky navržených zkoušek jsou prezentovány v Tab. 3. S rostoucím podílem popílku ve směsi roste také smrštění výpalem těchto směsí v důsledku vyššího množství tavících oxidů jako jsou oxidy železa a alkálie. Na druhou stranu má však vyšší podíl tavících oxidů pozitivní vliv na rychlost slinování a zhutnění struktury, což vede ke snižené pórovitosti a nasákavosti za současném zvyšování objemové hmotnosti a pevnosti. Tavící oxidy mají však negativní vliv na žárovzdornost a únosnost $\mathrm{v}$ žáru. Žárovzdornost směsí s popílkem byla snížena o $4 \%$ a únosnost v žáru $\mathrm{T}_{0,5}$ byla snížena o $6 \%$. Rozdíly mezi směsí s popílkem a reaktivním oxidem hlinitým tedy nebyly př́liš výrazné.

\begin{tabular}{|c|c|c|c|c|c|c|}
\hline Směs & VP10 & ROH10 & VP20 & ROH20 & VP30 & ROH30 \\
\hline Smrštění výpalem [\%] & 7,2 & 7,7 & 7,5 & 8,6 & 11,5 & 10,3 \\
\hline Zdánlivá pórovitost [\%] & 31,1 & 22,8 & 35,2 & 20,6 & 20,3 & 18,6 \\
\hline Nasákavost [\%] & 13,3 & 8,5 & 16,1 & 7,6 & 9,4 & 6,7 \\
\hline Objemová hmotnost $\left[\mathrm{kg} \cdot \mathrm{m}^{-3}\right]$ & 2340 & 2670 & 2190 & 2720 & 2230 & 2760 \\
\hline Žárovzdornost $\left[{ }^{\circ} \mathbf{C}\right]$ & 1695 & 1730 & 1670 & 1715 & 1645 & 1700 \\
\hline Únosnost $\mathrm{v}$ žáru $\mathbf{T}_{0,5}\left[{ }^{\circ} \mathrm{C}\right]$ & 1600 & 1645 & 1585 & 1645 & 1535 & 1660 \\
\hline Pevnost v tahu za ohybu [MPa] & 13,5 & 12,8 & 17,4 & 19,2 & 19,5 & 20,7 \\
\hline Reziduální pevnost v ohybu [\%] & 5,9 & 20,3 & 16,7 & 19,8 & 21,9 & 26,9 \\
\hline
\end{tabular}

Tab. 3 Výsledky prováděných zkoušek

$\mathrm{S}$ rostoucím podílem reaktivního oxidu hlinitého ve směsi roste také pevnost $\mathrm{v}$ tahu za ohybu. Pevnost se zvýšila z 12,8 MPa (směs ROH10) na 20,7 MPa (směs ROH30). Podobný trend sledovala také pevnost $\mathrm{v}$ tahu za ohybu u směsí s popílkem (VP10-VP30). S rostoucím podílem oxidu hlinitého ve směsi tedy vzrůstá podíl krystalů spinelu ve směsi, což vede ke zlepšení a zpevnění mikrostruktury a také pevností.

Toto zlepšení mikrostruktury je dokládáno prítomností spinelových krystalů na okrajích větších shluků forsteritových krystalů, jejich vzájemnému provázání a propojení krystalů spinelu zakotvených v amorfní skelné matrici, jak lze vidět na Obr. 1. Vylepšením mikrostruktury krystaly spinelu dochází také ke zlepšení odolnosti proti změnám teplot. Největší rozdíly jsou u směsí s popílkem, kdy reziduální pevnost v ohybu u směsi VP10 byla 5,9 \% a ve směsi VP30 již 21,9 \%.

Morfologie a mikrostruktura byla sledována pomocí rastrovacího elektronového mikroskopu a mikrofotografie jsou vyobrazeny na Obr. 1. Krystaly spinelu vznikly ve shlucích jak ve směsích s elektrárenským popílkem, tak ve směsích s reaktivním oxidem hlinitým. Morfologicky se jednalo o rombické dipyramidy o velikosti 2-4 $\mu \mathrm{m}$. Krystaly spinelu se nacházely na okrajích větších forsteritových zrn a také na jejich pomezí, spojující je dohromady. Krystaly spinelu, které byly syntetizovány ze směsí s reaktivním oxidem hořečnatým, byly rovnoměrnější s hladkým povrchem a bez trhlin či jiných nedokonalostí. Krystaly spinelu, které byly syntetizovány ze směsí s elektrárenským popílkem, měly trhliny s členitými a nepravidelnými hranami. Tento jev lze vysvětlit http://doi.org/10.51704/cjce.2021.vol7.iss01.pp35-43 
skutečností, že krystaly spinelu ze směsí s reaktivním oxidem hlinitým vznikají přímou syntézou tohoto oxidu s oxidem hořečnatým, zatímco krystaly spinelu ze směsi s popílkem vznikají nepř́mo z rozkladu mullitu na oxid hlinitý a oxid křemičitý a následně pak reakcí mezi oxidem hlinitým a hořečnatým.
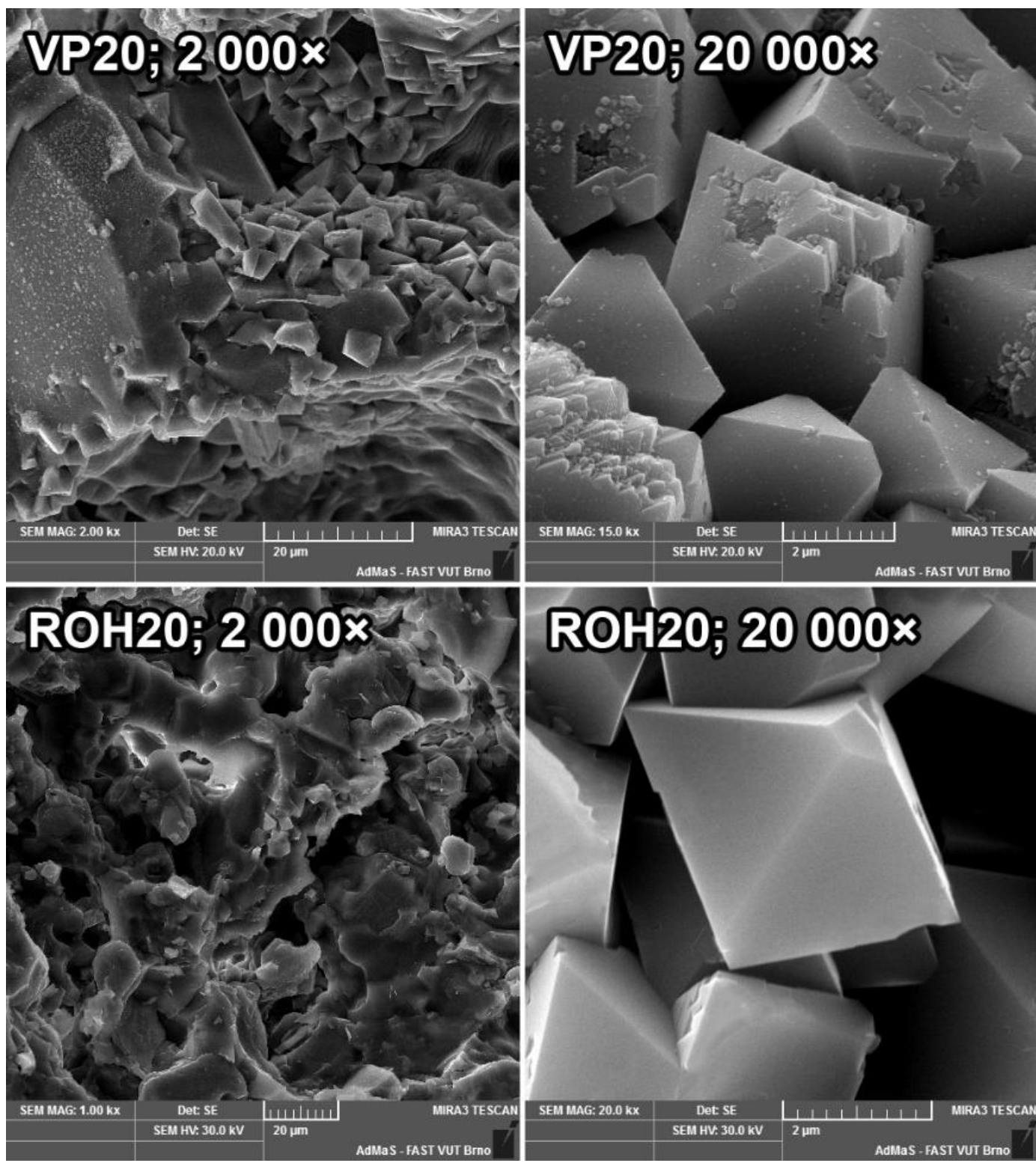

Obr. 1 Mikrofotografie z rastrovacího elektronového mikroskopu; směs s popílkem VP20 nahoře a směs $\mathrm{s}$ reaktivním oxidem hlinitým ROH20 dole

Výsledky RTG difrakční analýzy jsou zobrazeny na Obr. 2. Všechny směsi obsahují jako majoritní krystalickou fázi forsterit $\left(2 \mathrm{MgO} \cdot \mathrm{SiO}_{2}\right)$ a minoritní krystalické fáze spinel $\left(\mathrm{MgO} \cdot \mathrm{Al}_{2} \mathrm{O}_{3}\right)$, periklas $(\mathrm{MgO})$ a monticellit $\left(\mathrm{CaO} \cdot \mathrm{MgO} \cdot \mathrm{SiO}_{2}\right)$. Rozdíly mezi množstvím přidaného popílku nebo reaktivního oxidu hlinitého jsou pouze $\mathrm{v}$ intenzitě peaků spinelu. Př́tomnost oxidů železa je indikována šumem na pozadí, jenž je výraznější u směsí s vysokoteplotním popílkem VP10-VP30. Přítomnost amorfní skelné fáze je indikována zakřiveným pozadím při nízkých úhlech 2 theta $\left(5-25^{\circ}\right)$. 


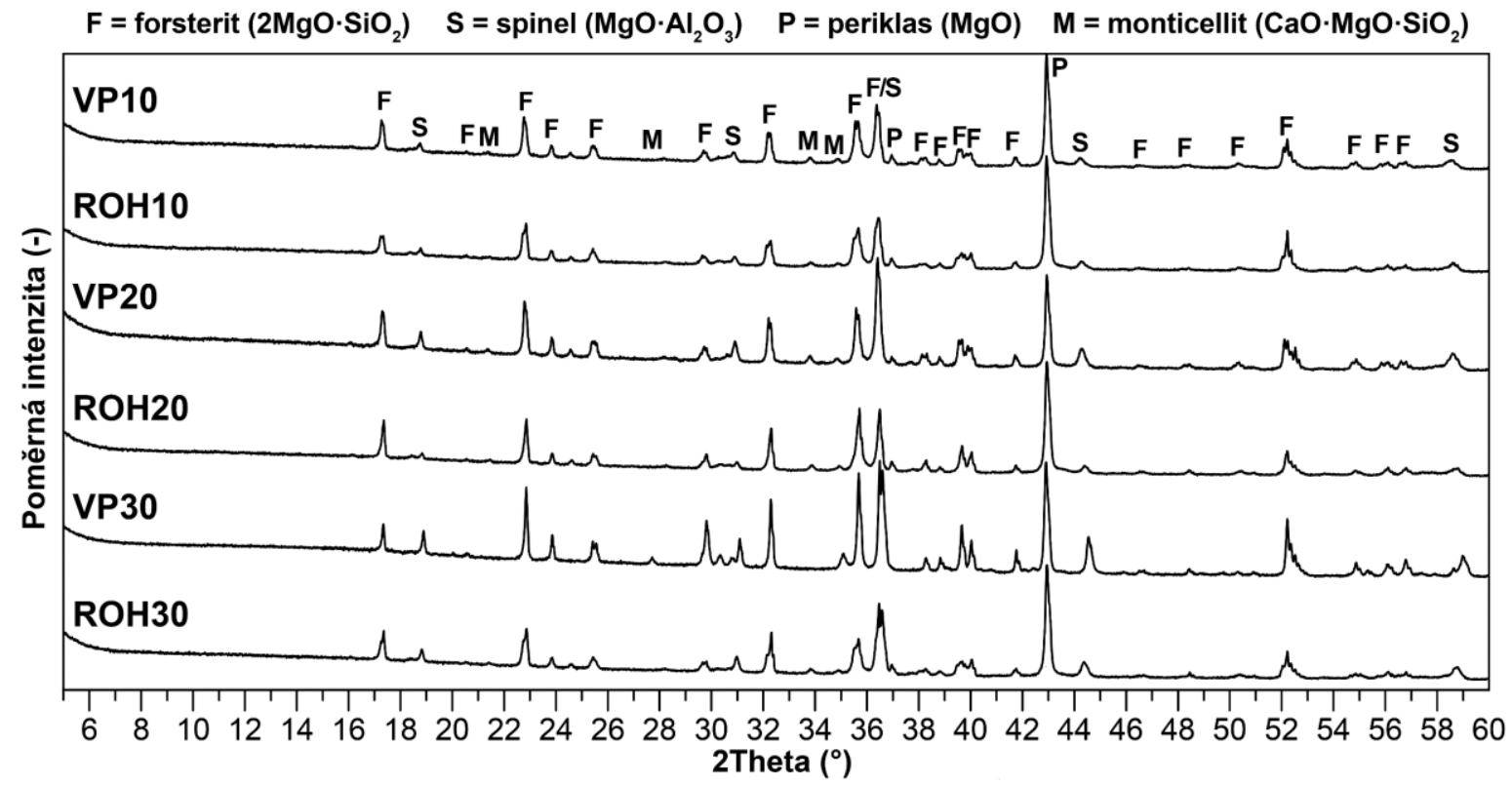

Obr. 2 Výsledky rentgenové difrakční analýzy všech navržených směsí

Dilatačně-kontrakční termická analýza směsí je prezentována na Obr. 3. Znatelné rozdíly mezi směsí s popílkem a reaktivním oxidem hlinitým byly pozorovány při teplotě nad $1000{ }^{\circ} \mathrm{C}$. Zkušební vzorky ze směsí s popílkem měly při zkoušce čtyři rozdílné fáze. V první fázi došlo $\mathrm{k}$ lineární expanzi vstupních surovin, která byla pozorována až do $1000{ }^{\circ} \mathrm{C}$, poté následovala fáze smrštování $\mathrm{v}$ teplotním intervalu $1000-1250^{\circ} \mathrm{C}$. Třetí pozorovaná fáze se vyznačovala expanzí v teplotním intervalu $1250-1350{ }^{\circ} \mathrm{C}$, jenž byla způsobena růstem krystalů mullitu a jeho následným rozkladem a reakcí s oxidem hořečnatým za vzniku spinelu, což vedlo také ke tvorbě kapalné skelné fáze. Toto chování bylo také pozorováno $\mathrm{v}$ jiných pracích $[15,16]$ a předchozím výzkumu $[17,18]$. Čtvrtá fáze nastala v teplotním intervalu nad $1350{ }^{\circ} \mathrm{C}$ a způsobila opětovné smršt'ování v důsledku působení tavících oxidů a kapalné skelné fáze na proces slinování.

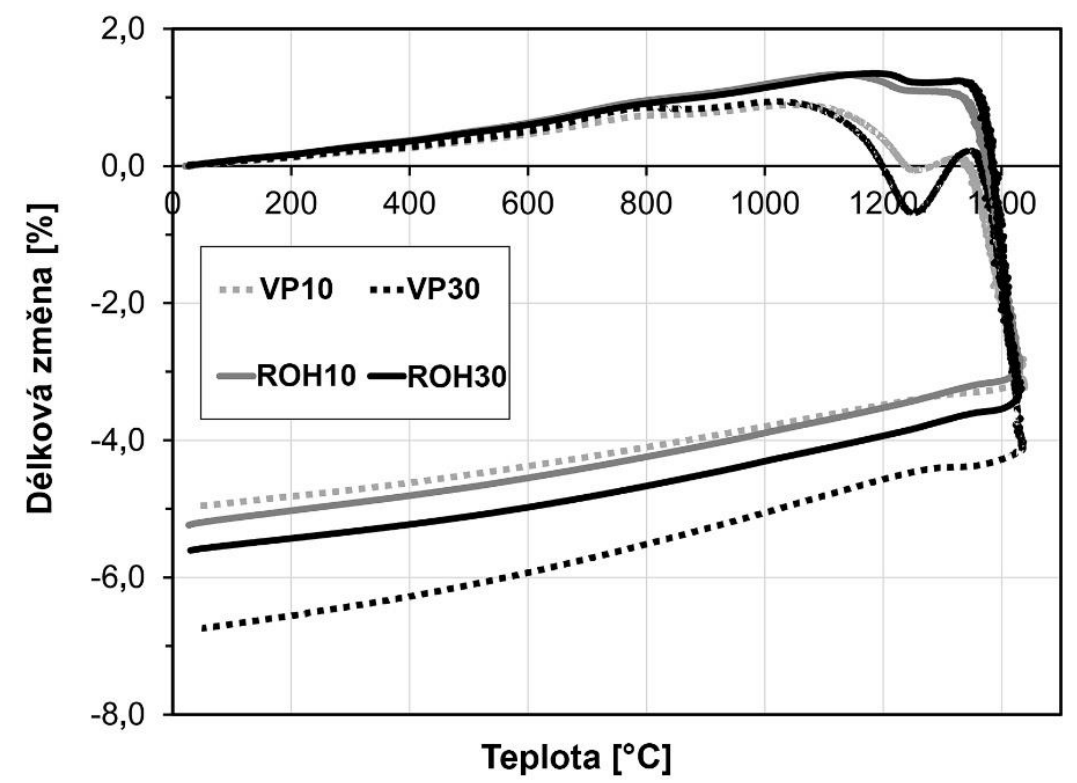

Obr. 3 Dilatačně-kontrakční termická analýza směsí s popílkem (tečkovaně) a reaktivním oxidem hlinitým (plnou čarou)

http://doi.org/10.51704/cjce.2021.vol7.iss01.pp35-43 
Vyhodnocení korozní odolnosti bylo provedeno pomocí rastrovacího elektronového mikroskopu, kde byly sledovány kontaktní zóny mezi železem a keramikou pro všechny směsi za využití detektoru zpětně odražených elektronů (BSE). Tento detektor dokáže rozlišit prvky s vyšším atomovým číslem, protože je intenzita zpětně odražených elektronů vyšší. Díky tomuto jevu lze pozorovat na Obr. 4 zřetelně rozdělené zóny mezi keramikou (tmavě šedá) a železem (bílá).

Vzorky s vysokoteplotním popílkem (VP10 a VP20) měly zvýšenou porozitu v blízkosti přechodné zóny mezi železem a keramikou z důvodu vytvoření fayalitu $\left(2 \mathrm{FeO} \cdot \mathrm{SiO}_{2}\right) \mathrm{z}$ oxidu železnatého $(\mathrm{FeO})$ a části amorfního oxidu křemičitého. Tento jev byl znatelnější ve vzorcích s obsahem elektrárenského popílku kvůli zvýšenému obsahu tavících oxidů (oxidy železa a alkálie) nacházejících se v popílku, které vedly $\mathrm{k}$ vytvoření vyššího množství amorfní skelné fáze při rozkladu mullitu a následné tvorbě spinelu. Ve směsích s reaktivním oxidem hlinitým se spinel tvořil přímo, a proto nedošlo k další tvorbě amorfní skelné fáze. Přechodná zóna mezi železem a keramikou také obsahovala olivín $(\mathrm{Mg}, \mathrm{Fe})_{2}\left[\mathrm{SiO}_{4}\right] \mathrm{s}$ vyšším podílem železa. Olivín je tuhý roztok mezi forsteritem $\left(2 \mathrm{MgO} \cdot \mathrm{SiO}_{2}\right)$ a fayalitem $\left(2 \mathrm{FeO} \cdot \mathrm{SiO}_{2}\right)$. Množství fayalitu v olivínu bylo v rozmezí 5-10 \% a v blízkosti přechodné zóny až 30 \%.

S rostoucím obsahem spinelu ve směsi (VP20, ROH20) byla přechodná zóna mezi železem a keramikou více zřetelná. To je způsobeno nízkou rozpustností spinelu působením oxidu železnatého. Korozní odolnost forsterit-spinelové keramiky účinkem železa byla tedy pouze minimální s hloubkou penetrace korozního média ve všech směsích pouze v desetinách milimetrů. Směsi s reaktivním oxidem hlinitým měly také nižší pórovitost $\mathrm{v}$ důsledku toho, že směsi s vysokoteplotním popílkem vytvářely spinel nepř́mo z rozkladu mullitu, jenž způsobil expanzi (Obr. 3).

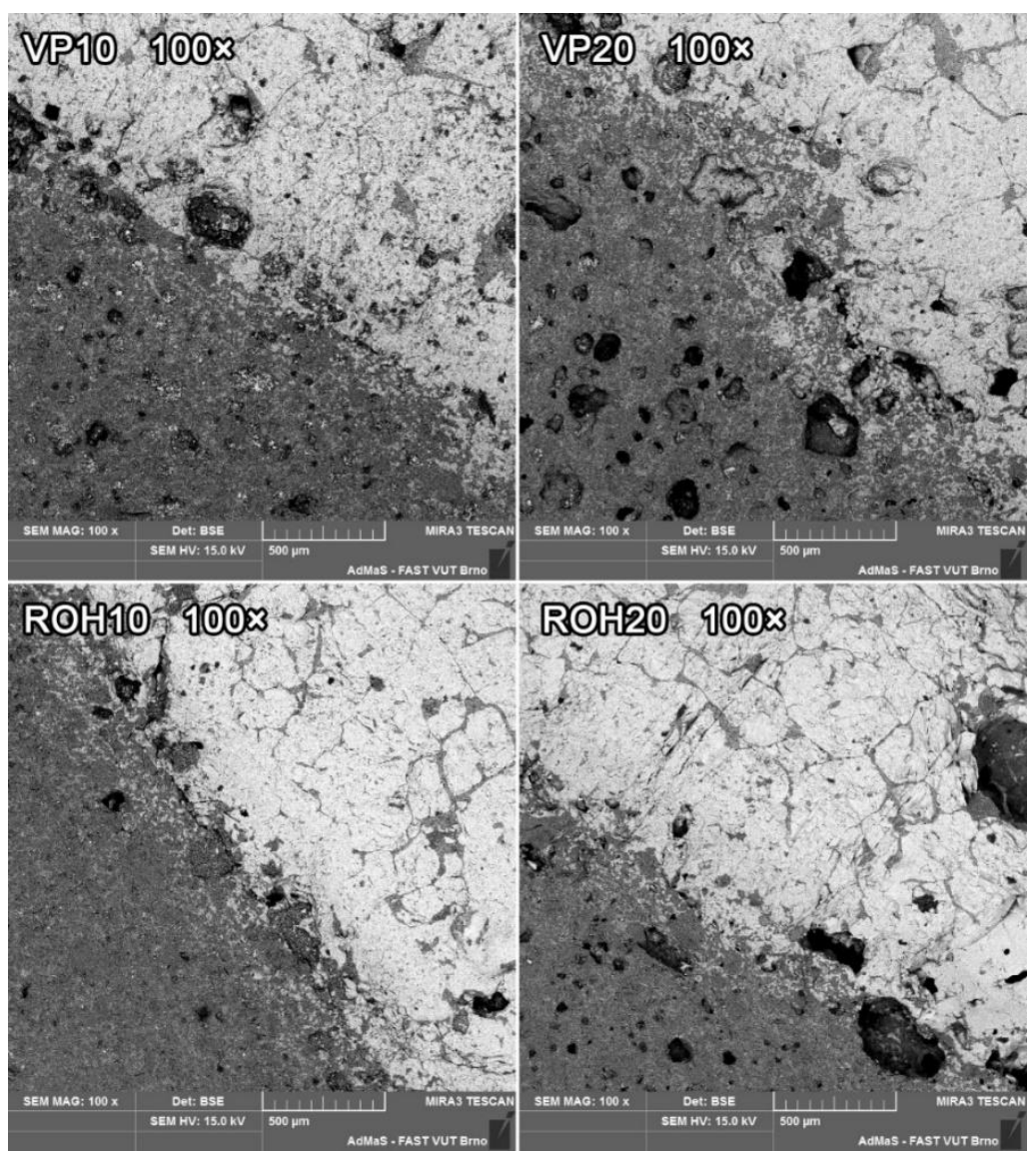

Obr. 4 Mikrofotografie z rastrovacího elektronového mikroskopu zobrazující korozní odolnost mezi keramikou (tmavě šedá) a železem (bílá) 


\section{ZÁVĚR}

Žárovzdorná forsterit-spinelová keramika byla syntetizována ze směsí s vysokoteplotním popílkem nebo reaktivním oxidem hlinitým jako vstupními materiály z důvodu porovnání jejich výsledných vlastností v závislosti na množství vzniklého spinelu a použitého zdroje oxidu hlinitého. Krystaly spinelu, které vznikly ze směsí s reaktivním oxidem hlinitým byly pravidelnější, monokrystalické. Nacházely se převážně na okrajích forsteritové matrice, kterou propojovaly společně s amorfní skelnou fází. Tím došlo ke zlepšení mikrostruktury a současně také ke zlepšení pevnosti v tahu za ohybu, odolnosti proti změnám teplot a korozní odolnosti.

Díky obsahu tavících oxidů (oxidy železa, alkálie) ve vysokoteplotním popílku se mullit, který je v popílku obsažen roztavil již pod jeho teplotou tavení, což umožnilo krystalizaci spinelu a vzniku skelné fáze. Nicméně ve směsi nad $20 \mathrm{hm}$. \% popílku bylo již množství tavících oxidů vysoké, což negativně ovlivnilo žárovzdorné vlastnosti. Směsi s popílkem byly také více pórovité, což bylo způsobeno prvotním růstem krystalů mullitu a následným vznikem pórů při změně modifikace oxidu křemičitého.

Při zkoušce korozní odolnosti vůči účinkům taveniny železa jeho část reagovala s forsteritem za tvorby olivínu s vyšším podílem fayalitu. Podíl fayalitu byl vyšší v blízkosti přechodné zóny mezi železem a keramikou. Díky nízké rozpustnosti spinelu v oxidu železa byla s vyšším obsahem spinelu ve směsi také zlepšena korozní odolnost. Celková hloubka penetrace železa do keramiky byla pouze v desetinách milimetrů ve všech směsích.

Závěrem, s vyšším podílem spinelu ve forsteritové keramice dochází ke zlepšení mikrostruktury, pevnosti v tahu za ohybu, odolnosti proti změnám teplot a korozní odolnosti. Vysokoteplotní popílek lze také využít, avšak pouze v množství do $20 \mathrm{hm}$. \%.

\section{Poděkování}

Tento př́spěvek byl podpořen $\mathrm{v}$ rámci řešení juniorského grantu specifického výzkumu pod interní grantovou agenturou Vysokého učení technického v Brně s číslem FAST-J-20-6196 a názvem: Vývoj žárovzdorných materiálů na bázi forsterit-spinel-magnezit s ohledem na odolnost proti korozi různými korozivními médii.

\section{Použitá literatura}

[1] BUDNIKOV, P. P. a kolektiv. Technologie keramiky a žárovzdorného zboží. Praha: Státní nakladatelství technické literatury, 1960, ISBN 9780262523776.

[2] KINGERY, W. Introduction to ceramics. New York: Wiley, 1960, xvi, 781 s. ISBN 04-7147883-0.

[3] ZHAO, Fei, Lixin ZHANG, Zhen REN, Jinxing GAO, Xiaoyu CHEN, Xinhong LIU a Tiezhu GE. A novel and green preparation of porous forsterite ceramics with excellent thermal isolation properties, Ceramics International, 2019, 45(3), pp. 2953-2961, ISSN 02728842, https://doi.org/10.1016/j.ceramint.2018.09.296

[4] BOUHIFD, M. A., D. ANDRAULT, G. FIQUET a P. RICHET. Thermal expansion of forsterite up to the melting point, Geophysical research letters, 1996, 23(10), pp. 1143-1146.

[5] HEILMANN, F.; Rixecker, G.; Börner, F.D.; Lippmann, W.; Hurtado, A. Fe2O3-doped forsterite ceramics as a joining partner for $\mathrm{ZrO} 2$ in a laser brazing process. Journal of European Ceramics Society, 2009,

29, pp.

2783-2789, https://doi.org/10.1016/j.jeurceramsoc.2009.03.028 
[6] MUSTAFA, E.; Khalil, N.; Gamal, A. Sintering and microstructure of spinel-forsterite bodies. Ceramics International 2002, 28, pp. 663-667, https://doi.org/10.1016/S0272-8842(02)000251

[7] EWAIS, E.M.M.; El-Amir, A.A.M.; Besisa, D.H.A.; Esmat, M.; El-Anadouli, B.E.H. Synthesis of nanocrystalline $\mathrm{MgO} / \mathrm{MgAl} 2 \mathrm{O} 4$ spinel powders from industrial wastes. Journal of Alloys and Compounds. 2017, 691, pp. 822-833, https://doi.org/10.1016/j.jallcom.2016.08.279

[8] KUMAR, M.S.; Vanmathi, M.; Senguttuvan, G.; Mangalaraja, R.V.; Sakthivel, G. Fly Ash Constituent-Silica and Alumina Role in the Synthesis and Characterization of Cordierite Based Ceramics. Silicon 2018, 11, pp. 2599-2611, https://doi.org/10.1007/s12633-018-0049-0

[9] REN, Q.; Ren, Y.; Wu, X.; Bai, W.; Zheng, J.; Hai, O. Effect mechanism of spinel (MgAl2O4) reinforced corundum ceramics on microstructure and properties. J. All. Com. 2019, 793, pp. 146-154, https://doi.org/10.1016/j.jallcom.2019.04.151

[10] TAVANGARIAN, F.; Emadi, R. Synthesis of pure nanocrystalline magnesium silicate powder. Ceram. Silikat. 2010, 54, pp. 122-127, ISSN 1804-5847.

[11] NGUYEN, M.; Sokolár, R. Formation and Influence of Magnesium-Alumina Spinel on Properties of Refractory Forsterite-Spinel Ceramics. Materiali in Tehnologije, 2020, 54, pp. 135-141, https://doi.org/10.17222/mit.2019.198

[12] NGUYEN, Martin a Radomír SOKOLÁŘ. Impact of Fly Ash as a Raw Material on the Properties of Refractory Forsterite-Spinel Ceramics. Minerals. 2020, 10(9). ISSN 2075-163X. https://doi.org/10.3390/min10090835 